\title{
Pedagogy before technology: Understanding the confidence of vocational educators for integrating technology enhanced learning
}

\author{
Robert Vanderburg, Michael Cowling, Joanne Dargusch \\ CQUniversity Australia
}

\begin{abstract}
This project investigated VET educators' perspectives of the usefulness and ease-of-use of technology in their units, including the difficulties they had implementing technology. VET Teachers were offered a one-day 'bootcamp' style workshop where they were introduced to innovative technology for the classroom. A significant amount of time in the workshops was spent mapping VET pedagogy and technology using the 'pedagogy before technology' approach. The study was designed as an action research project with a combination of quantitative and qualitative questions delivered via survey at the conclusion of the workshop. For the first loop of the project, 23 educators answered 11 quantitative questions based on the Technology Acceptance Model (TAM) targeting their perception of the usefulness of technology and its ease-of-use in delivering their units, with qualitative evidence gathered in the form of field notes by researchers as participant observers. The results revealed VET educators had a high level of confidence in their understanding of technology and their ability to learn about technology. However, they lacked confidence in implementing technology in their pedagogical practices. Specifically, whilst they had average confidence using technology to teach simple concepts, they lacked confidence in using technology to teach complex concepts and adequately assess their students.
\end{abstract}

Keywords: Pedagogy, Technology, Workshop, Vocational Education, Technology Acceptance

\section{Introduction}

A concern frequently raised in the literature is of the disconnect between training of Vocational Education and Training (VET) educators and the dynamic context of the contemporary classroom (Smith \& Yasukawa, 2017). Issues surrounding the use of technology in pedagogy form part of this conversation. Whilst the need for VET educators to develop a range of pedagogical strategies incorporating technology to facilitate flexible learning environments is increasingly apparent in contemporary time, the extent to which this happens in practice is less clear.

Empirical studies conducted in Higher Education (Bower, Cram, \& Groom, 2010; Bower, Lee \& Dalgarno, 2017) demonstrate a clear desire for a focus on Blended Learning (specifically the use of media-rich synchronous technologies to enable remote and face-to-face students to co-participate in the same live classes) into the future, with a focus on how online can be blended into existing physical skills training of the type that is routine in the VET space. Meanwhile, scholars such as Banas \& Velez-Solic (2013) argue that VET educators are ill-prepared for this change, and that a careful approach to pedagogy and technology in VET needs to be taken. Limited evidence exists of VET teachers' perceptions of technology and its use in the on-line environment.

It is against this backdrop that authors 1 and 2 were inspired to conduct training with VET teachers on the innovative use of technology in their classroom context, collecting data on perceptions of educators at the conclusion of the workshop as part of the first loop in an action research-based project. Specifically, the project sought feedback from the participants (drawn from across a range of VET teaching areas) in one dual-sector university, after completing training in the use of technology for instruction, pedagogy, and assessment. 
Our research question involved examining VET educators' perceptions of their ability to use technology in their units. More specifically, we investigated their perception of their ability to use technology going forward, and their perception of their ability to integrate technology in their pedagogy and assessments. Data collection and analysis will enable the university to better respond to issues related to the use of technology with VET teachers and the insights gained will be used to create a set of recommendations about how to best support VET teachers in their use of technology.

\section{Background}

Notions of teaching have become more complex in the VET sector, with VET teachers expected to work in diverse environments with groups of students with diverse learning needs. As Vocational Education in Australia meets "its responsibilities to skill and upskill current and future workers" (Cox \& Prestridge, 2020 p. 11), online education offerings are increasingly expanding, opening possibilities in terms of employing technologies to support teaching. However, anecdotal information indicates that many VET teachers feel that they do not have the skills to utilise all the technologies available to them.

Despite assertions that use of technology to deliver VET courses is going to become essential into the future (Maclean \& Lai, 2011), there are identified barriers to its nascent adoption across the sector. The first of these is at a system level, with Latchem (2017, pp 28) identifying the lack of "systemic application of ICTs across the sector in ways that will achieve the fundamental transformation of education and training that is called for", and Schmidt (2017) emphasising the influence of strategic views and directions at the system level on teacher uptake of technologies. The second sits with the perceived lack of familiarity of individual teachers with "new technologies and methodologies" (Latchem, 2017, p. 29).

Research indicates that the transition from teaching face-to-face to the online teaching environment can be problematic, with teachers not adequately prepared (Banas \& Velez-Solic, 2013; Bound, 2011; Cox, \& Prestridge, 2019), and little "understood about the pedagogy of VET online" (Cox \& Prestridge, 2020, p. 15). VET teachers teaching online are required to both embed technology for the purposes of facilitating learning, and develop pedagogies associated with using such technologies. This involves moving away from a predominantly instructional pedagogy that has traditionally been associated with the 'delivery' of competency-based training and training packages that are highly structured with required levels of oversight and compliance (Bound, 2011).

Research calls for the evolution of "online teaching and learning pedagogy beyond technical expertise" (Mason \& Carr, 2020, p. 5), with the need to develop VET teachers' understanding and skills in the pedagogies associated with engaging and student-centric online education. This means that engaging VET educators is essential in order to consider "the complex interrelatedness of learning and the affordances of the [online] environment" (Mason \& Carr, 2020 , p. 5). VET teachers themselves have identified the importance of learning technologies as part of pedagogical design (Zgraggen, 2021). However, these are considered by VET teachers to be 'advanced' skills, with research participants contending that very experienced VET teachers may "have no concept of how to facilitate and motivate a student through an online delivery mode" (Schmidt, p. 50). Accordingly, whether VET teachers themselves are confident in their readiness for such shifts in teaching practice is unknown, with only very recent research exploring their perceptions of, and attitudes to, teaching in the online environment (Cox \& Prestridge, 2020).

Against this backdrop is a clear desire to push forward with a blended or online model, driven in recent times by the COVID-19 pandemic. However, even prior to the pandemic, key scholars argued that the physical model would have to give way to a more blended future (Bower, Lee \& Dalgarno, 2017). Moreover, small scale studies postCOVID-19 have shown that even as the pandemic eases, students still value the flexibility that a (so-called) Hyflex environment offers (Khonke \& Moorhouse, 2021). But there is still work to be done to adjust the process of operationalising pedagogy for this new mode of learning, and to understand VET teachers' level of comfort and motivation towards using technology to facilitate teaching in a blended or online model.

A common resource used to understand how technology will be accepted is the Technology Acceptance Model (TAM). Proposed by Venkatesh, Morris, Davis \& Davis (2003), the TAM suggests two components important for technology acceptance, Perceived Usefulness and Perceived Ease of Use. In summary, this means that the authors proposed that for a technology to be well accepted it not only needs to be easy to use but also useful for the parties 
working with the technology. For an academic audience, this means that a technology under use needs to solve a pedagogical problem in a way that makes teaching easier. Whilst perhaps in the pandemic this was easier due to the lack of choice, post-pandemic consideration needs to be given to ensure that this pedagogical value is provided.

A potential model that could be used to understand this is the Pedagogy before Technology (PBT) model proposed by Cowling \& Birt (2018). In the PBT model, pedagogy is put first via the use of three guiding questions. Academic teachers are asked first to identify their pedagogical problem, then a solution to this problem, and only then propose a technology that might be used to solve this problem. In this way, the parameters of the TAM are more likely to be covered, as teachers are confident that the usefulness of the technology is satisfied, leaving the only question relating to the ease of use of the technology. Our intervention looked to consider how to address this question through targeted training by Educational Technology experts for VET staff.

\section{Methodology}

This project was an action research project based on the action research spiral of action, reflection, action, reflection (Norton, 2018). This paper presents the first cycle of this project, with action described in detail as part of the intervention design section, and results showing the process of reflection that will lead to further action. The study took place at a dual-sector university based in regional Queensland. VET courses are offered through face-to-face and distance mode. The students at this university study flexibly from various locations around Australia; they come from a diverse range of socio-economic backgrounds, cultures, and life-stages. Participants were recruited via a voluntary process initiated by the Director of VET Studies to be involved in the training and research.

The technology education training program was conducted with 23 VET educators. The university sent an email to all the VET instructors at the university offering training utilising technology to improve their pedagogy. These 23 educators chose to attend the training. There were $14(61 \%)$ females and nine (39\%) males in the training. The training was conducted at a university based in Queensland. The students at this university study flexibly from various locations around Australia; they come from a diverse range of socio-economic backgrounds, cultures, and life-stages. Ethics to conduct the survey was obtained from the institutions Human Research Ethics Committee (HREC).

The training was broken into two parts. The first part of the training educated the VET educators on an array of different technologies relevant to educating students. The second part of the training was based on a Pedagogy before Technology framework in which the educators were trained on ways to use technology to improve instruction. After the training, we asked the educators to fill out a survey demonstrating their perceptions of how they can understand and utilise technology and how they perceive their ability to utilise technology to instruct and assess their students. The goal of this survey was to infer what the VET educators perceived were the areas of technology training they still needed.

\section{Intervention Design}

For this work, VET teachers were offered a one-day 'bootcamp' style workshop where they were introduced to innovative technology for the classroom. The training was broken into two parts. The first part of the training educated the VET educators on an array of different technologies relevant to educating students. The educators were trained on how to use Moodle, how to use VR headsets, how to use Microsoft Teams, and how to use Echo to record trainings. This section of the workshop was purely focused on how to use the technology at a high level, discussing the details of the functionality of the technology rather than deep technical requirements, to ensure this would fit within the timeframe. We did not provide any training on how to use the technology to improve instruction until the second section of the training.

During the second part of the bootcamp, a significant amount of time in the workshops was spent mapping VET pedagogy and technology using the 'pedagogy before technology' approach (Cowling \& Birt, 2018). In this section, the educators learned how they can improve their abilities to instruction by providing videos which 'flip' the classroom as a mechanism to improve instruction (Moffett, 2014). They were also trained in how to implement VR components to improve their instruction. The educators were provided ways to use technology to integrate 
assessment and instruction. Finally, they were provided with ways to use technology to provide personalised instruction for students who were struggling with concepts.

\section{Measure}

The survey we used included 11 items adapted from the Motivated Strategies for Learning Questionnaire (MSLQ: Pintrich, Smith, Garcia, \& Mckeachie, 1991), reflecting the identified need in the literature to consider carefully the motivation and attitudes of teachers to teaching online. These 11 items were selected due to their relevance to instruction and the use of technology. Similar adaptions use a Likert (Likert, 1932) scale format and have been used to measure metacogntive abilities (Bjork Dunlosky \& Kornell 2012; Crede \& Phillips, 2011; Pintrich 2004). The educators were asked 11 questions about their motivation for and attitudes towards technology.

1) If I learn about technology ways, then I will be able to use technology in my university course

2) If I try hard enough, then I can effectively use technology to instruct the course material

3) I don't understand how to use technology to instruct the course material

4) I believe my students will receive excellent grades in the units I use technology to instruct my students

5) I'm certain I can understand how to use technology to instruct the units I teach

6) I'm confident I can use technology to instruct the basic concepts taught in the units I teach

7) I'm confident I can use technology to instruct the most complex material presented in the units I teach

8) I'm confident I can use technology to instruct the assignments and tests in the units I teach

9) I expect to do well using technology to instruct students

10) I'm certain I can master the ability use to technology to instruct my units

11) Considering the difficulty of technology, I think I will do well using technology to instruct the units I teach.

Within the context of the instrument, these questions were broken down into two sections. Section one measured educators' perceptions of their ability to use technology (i.e., questions 1,2, 10 and 11), and section two measured educators' perceptions of their ability to use technology in instruction (i.e., questions 3, 4, 5, 6, 7, 8 and 9). The survey itself was administered on paper, with results transcribed into a spreadsheet for analysis using SPSS.

\section{Results}

The first analysis conducted were independent t-tests to ascertain if gender influenced the results of the survey. The t-test run on all 11 questions demonstrated there were no significant differences in the responses based on gender. These results enabled us to interpret the frequencies of the survey confident that the results reflected the entire group. The results of the histograms revealed that after a technology training the VET educators perceived they were more motivated to use technology in their units. However, the educators perceived themselves as less motivated to use technology to instruct students.

Figure 1. Number of responses per answer for Q1

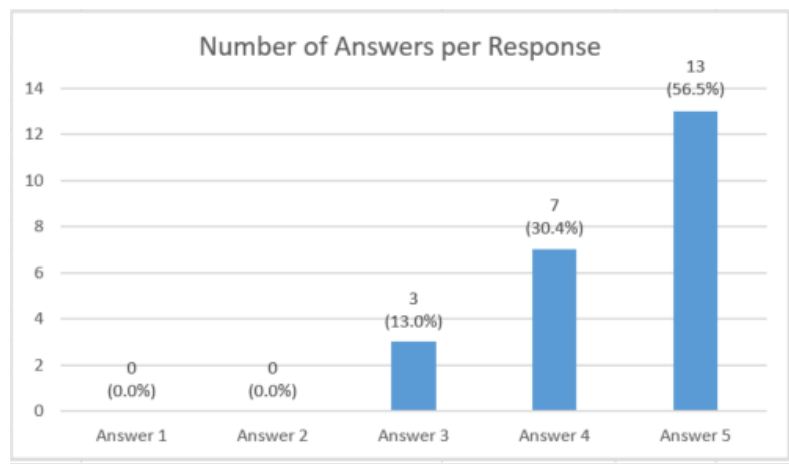

\section{Figure 2. Number of Responses per answer for Q2}

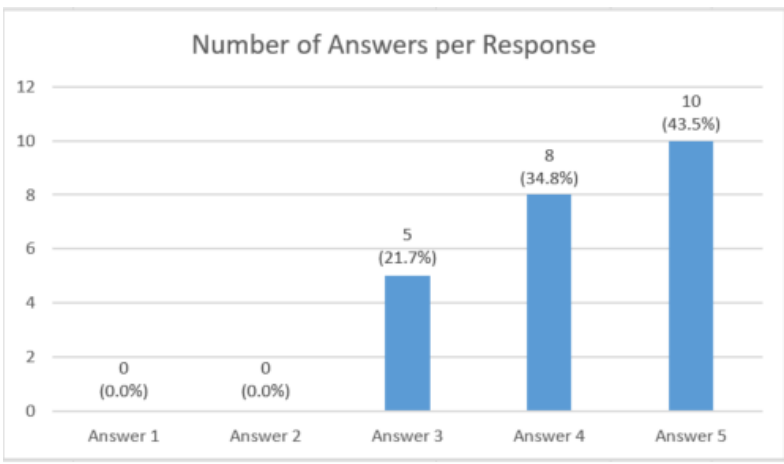

The questions centred on using technology were questions $1,2,10$ and 11. The mean score for these questions were 4.06. Question 1 was if I learn about technology ways, then I will be able to use technology in my university course. As seen in Figure 1, 56.5\% of the VET educators selected a five, the highest score demonstrated they perceived this 
question as true, $30.4 \%$ of the VET educators selected a four, $13 \%$ of the VET educators selected a three, and $0 \%$ of the VET educators selected a two or one. Question 2 was if I try hard enough, then I can effectively use technology to instruct the course material. As seen in Figure 2, 43.5\% of the VET educators selected a five, the highest score demonstrated they perceived this question as true, $34.8 \%$ of the VET educators selected a four, $21.7 \%$ of the VET educators selected a three, and $0 \%$ of the VET educators selected a two or one.

Figure 3. Number of responses per answer for Q10

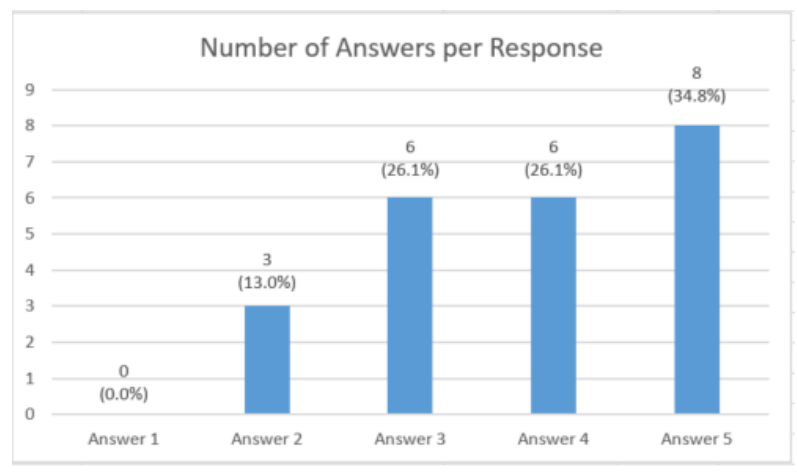

Figure 4. Number of Responses per answer for Q11

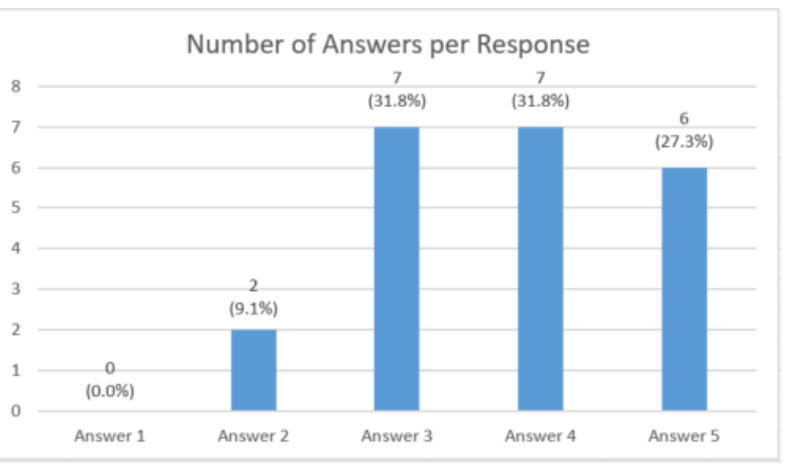

Question 10 was I'm certain I can master the ability use to technology to instruct my units. As seen in Figure 3, $34.8 \%$ of the VET educators selected a five, the highest score demonstrated they perceived this question as true, $26.1 \%$ of the VET educators selected a four, $26.1 \%$ of the VET educators selected a three, $13 \%$ of the VET educators selected a two, and $0 \%$ of the VET educators selected one. Question 11 was considering the difficulty of technology, I think I will do well using technology to instruct the units I teach. As seen in Figure 4, 26.1\% of the VET educators selected a five, the highest score demonstrated they perceived this question as true, $30.4 \%$ of the VET educators selected a four, $30.4 \%$ of the VET educators selected a three, $8.7 \%$ of the VET educators selected a two, and $0 \%$ of the VET educators selected one.

Figure 5. Number of responses per answer for Q3 Figure 6. Number of Responses per answer for Q4
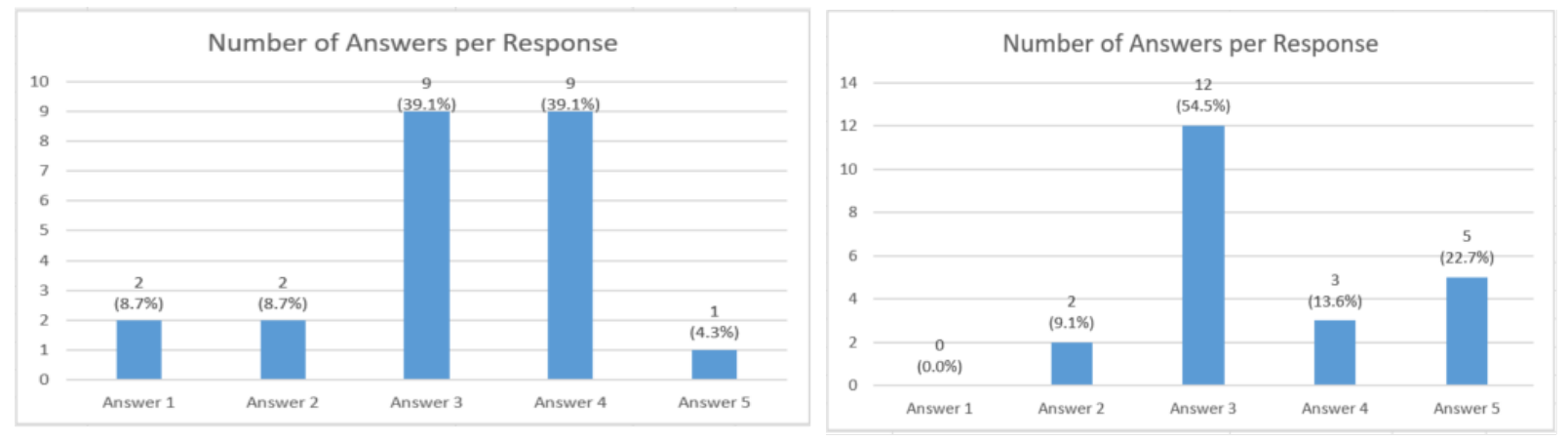

The questions which centre on how the educators perceived themselves as motivated to use technology to instruct students were questions 3, 4, 5, 6, 7, 8, and 9. The mean score for these questions were 3.39. Question 3 was I don't understand how to use technology to instruct the course material. As seen in Figure 5, 4.3\% of the VET educators selected a five, the highest score demonstrated they perceived this question as true, $39.1 \%$ of the VET educators selected a four, $39.1 \%$ of the VET educators selected a three, $8.7 \%$ of the VET educators selected a two, and $8.7 \%$ of the VET educators selected one. Question 4 was I don't understand how to use technology to instruct the course material. As seen in Figure 6, 21.7\% of the VET educators selected a five, the highest score demonstrated they perceived this question as true, $13 \%$ of the VET educators selected a four, $52.2 \%$ of the VET educators selected a three, $8.7 \%$ of the VET educators selected a two, and $0 \%$ of the VET educators selected one. 
Figure 7. Number of responses per answer for Q5 Figure 8. Number of responses per answer for Q6
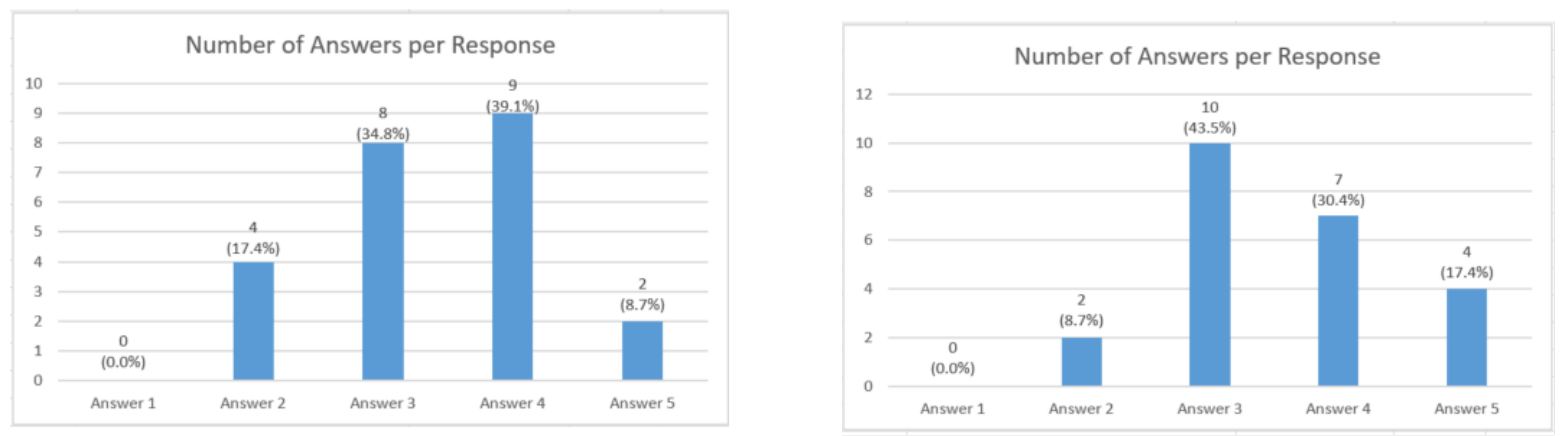

Question 5 was I believe my students will receive excellent grades in the units I use technology to instruct my students. As seen in Figure 7, 17.4\% of the VET educators selected a five, the highest score demonstrated they perceived this question as true, $30.4 \%$ of the VET educators selected a four, $43.5 \%$ of the VET educators selected a three, $8.7 \%$ of the VET educators selected a two, and $0 \%$ of the VET educators selected one. Question 6 was I'm confident I can use technology to instruct the basic concepts taught in the units I teach. As seen in Figure 8, 8.7\% of the VET educators selected a five, the highest score demonstrated they perceived this question as true, $39.1 \%$ of the VET educators selected a four, $34.8 \%$ of the VET educators selected a three, $17.4 \%$ of the VET educators selected a two, and $0 \%$ of the VET educators selected one. Question 7 was I'm confident I can use technology to instruct the most complex material presented in the units I teach. As seen in Figure 9, 8.7\% of the VET educators selected a five, the highest score demonstrated they perceived this question as true, $26.1 \%$ of the VET educators selected a four, $56.5 \%$ of the VET educators selected a three, $8.7 \%$ of the VET educators selected a two, and $0 \%$ of the VET educators selected one.

Figure 9. Number of responses per answer for Q7

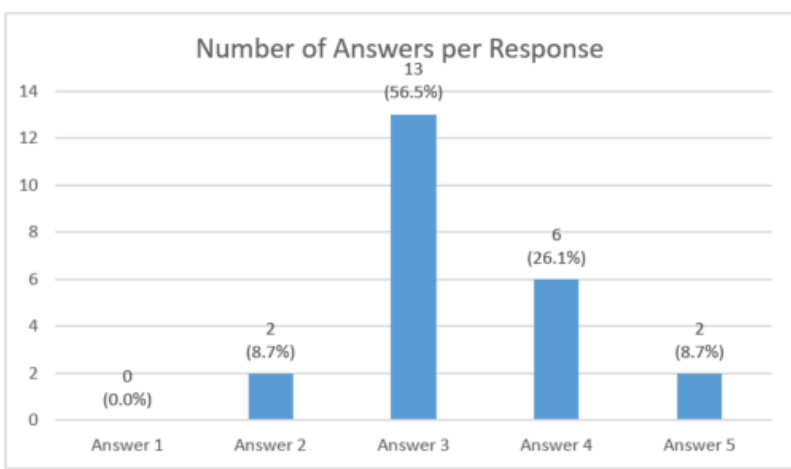

Figure 10. Number of Responses per answer for Q8

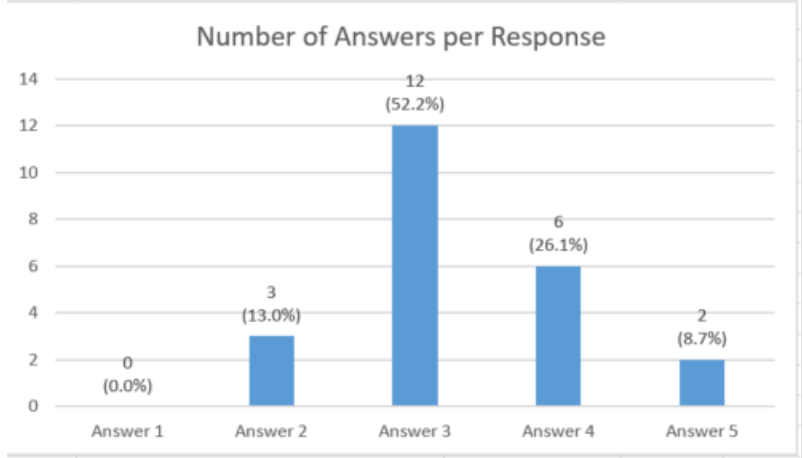

Question 8 was I'm confident I can use technology to instruct the assignments and tests in the units I teach. As seen in Figure 10, 8.7\% of the VET educators selected a five, the highest score demonstrated they perceived this question as true, $26.1 \%$ of the VET educators selected a four, $52.2 \%$ of the VET educators selected a three, $13 \%$ of the VET educators selected a two, and $0 \%$ of the VET educators selected one. Question 9 was I expect to do well using technology to instruct students. As seen in Figure 11,17.4\% of the VET educators selected a five, the highest score demonstrated they perceived this question as true, $34.8 \%$ of the VET educators selected a four, $34.8 \%$ of the VET educators selected a three, $13 \%$ of the VET educators selected a two, and $0 \%$ of the VET educators selected one. 
Figure 11: Number of responses per answer for $Q 9$

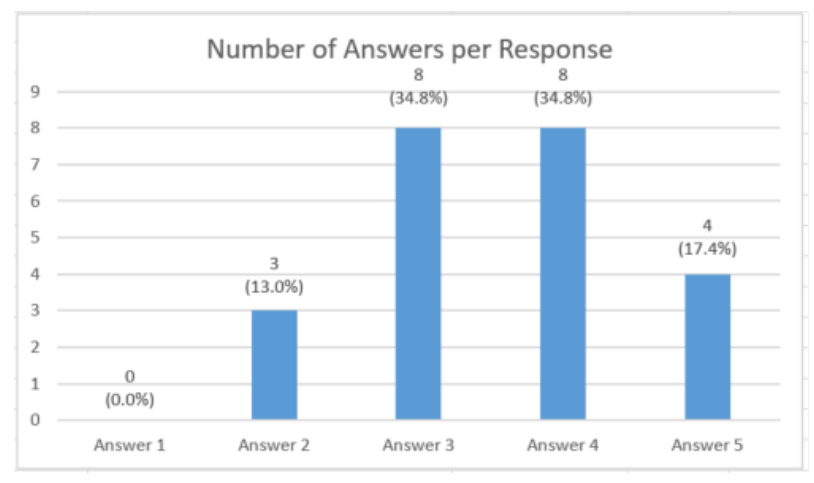

\section{Discussion}

This research project provided the opportunity to investigate VET teachers' perceptions of their use of technology. Specifically, the questions will ask them to reflect on their learning and teaching experiences so that they can make more informed decisions in their teaching practice (Brookfield, 2015) in relation to their use of technology. The NCVER has recently promoted the use of applied research to develop the VET sector, with a focus on strengthening VET's standing in relation to innovation in Australia (Simon \& Beddie, 2017). This research project provides an opportunity to contribute to this conversation.

There were two clear findings from these results. Firstly, the results revealed that VET educators perceived they had greater ability to use technology in their units. Many of the VET educators provided perception scores of five. In addition, VET educators perceived that they had the ability to learn how to use technology. Most of the VET educators provided a score of four or five to demonstrate they could learn how to use technology. This suggests that in line with TAM (Venkatesh, Morris, Davis \& Davis, 2003), VET educators have a clear high perception of the ease of use of the technology that they must use in teaching, in support of the work of Mason and Carr (2020). Specifically, in applying the TAM framework, the teachers indicated through these results a clear support of the 'ease of use' metric within that framework, indicating that they either found the technology easy to use, or that they felt that they could learn how to use the technology without issue.

However, the second finding of this study was that VET perceived they needed more support with understanding how technology can be utilised in their units and how to improve instruction due to implementing technology in their pedagogy. Many of the VET educators did not provided score of five on the questions addressing using technology in their units, on the questions addressing if they felt they could use technology to instruct their students, on the questions addressing if they could use technology to assess their students, and on the questions addressing the notion of students learning more in their units due to the use of technology.

Unpacking the work of Cox and Prestridge (2020) therefore, these findings demonstrate that VET educators do not really need more training in technology; rather, VET educators need training on using technology to improve pedagogy, to improve assessment and to improve learning in their units. Or in the parlance of the TAM framework, it's clear that whilst VET educators were happy with the 'ease of use' measure, there is still more work to be done to ensure that technology has a clear 'usefulness' for these educators.

Hence, a possible outcome would be to add the PBT framework (Cowling \& Birt, 2018) to future trainings and educational development of VET educators, with additional TAM components that ensure that this usefulness concept is more clearly applicable for VET educators. Specifically, the components of TAM could be combined with the PBT, emphasising the key aspects of 'ease of use' and 'usefulness' as a component of each question. A model mixing the PBT and TAM frameworks has been mapped out below: 


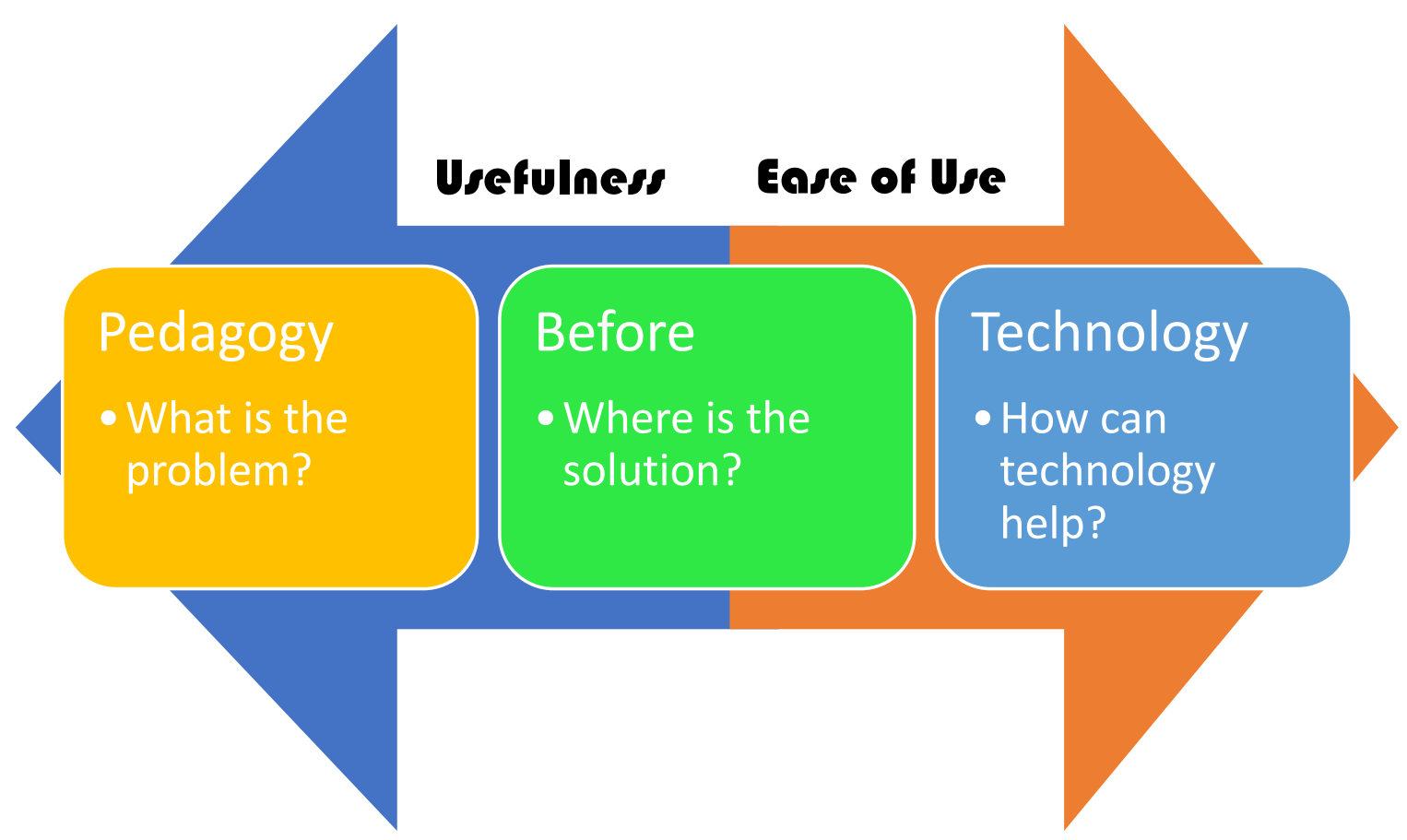

\section{Conclusion}

The need to investigate VET teachers' online teaching has been thrown more sharply into relief in recent times, as a result of the pandemic hastening moves towards online learning in VET. The importance of pedagogies associated with online learning is now more important than ever. This study was designed as an action research project with a combination of quantitative and qualitative questions delivered via survey during a workshop. The results revealed VET educators had a high level of confidence in their understanding of technology and their ability to learn about technology. However, they lacked confidence in implementing technology in their pedagogical practices.

Specifically, whilst teachers had average confidence using technology to teach simple concepts, they lacked confidence in their ability to use technology to teach complex concepts and adequately assess their students. Overall, the study showed that VET educators need less training on how to use technology at a high level and that the functionality of the technology is often something that can be determined intuitively. However, future training should instead focus more on how technology maps to pedagogy and its use in the classroom, particularly in developing assessment.

\section{References}

Ally, M. (Ed.). (2009). Mobile learning: Transforming the delivery of education and training. Athabasca University Press. https://www.aupress.ca/books/120155-mobile-learning/

Banas, J. R., \& Velez-Solic, A. (2013). Designing effective online instructor training and professional development. In J.Keengwe, \& L. Kyei-Blankson (Eds.), Virtual mentoring for teachers: Online professional development practices, (pp. 1-25). IGI Global. https://doi.org/10.4018/978-1-4666-1963-0.ch001

Bannister, B., Cornish, L., Bannister-Tyrrell, M., \& Gregory, S. (2015). Creative us of digital technologies: Keeping the best and brightest in the bush. Australian and International Journal of Rural Education, 25(1), 52-65.

Beetham, H., \& Sharpe, R. (Eds.). (2013). Rethinking pedagogy for a digital age: Designing for 21 st century learning (2nd ed.). Routledge Taylor \& France Group. https://doi.org/10.4324/9780203961681 
Bound, H. (2011). Vocational education and training teacher professional development: tensions and context. Studies in Continuing Education, 33(2), 107-119, https://doi.org/10.1080/0158037X.2011.554176

Bower, M., Cram, A., \& Groom, D. (2010). Blended reality: Issues and potentials in combining virtual worlds and face-to-face classes. In C. H. Steel, M. J. Keppell, P. Gerbic, \& S. Housego (Eds.), Curriculum, technology \& transformation for an unknown future - Proceedings of the 27th ASCILITE Conference (pp. 129-140). The University of Queensland. https://www.ascilite.org/conferences/sydney10/procs/Bower-full.pdf

Bower, M., Lee, M. J., \& Dalgarno, B. (2017). Collaborative learning across physical and virtual worlds: Factors supporting and constraining learners in a blended reality environment. British Journal of Educational Technology, 48(2), 407-430. https://doi.org/10.1111/bjet.12435

Bjork, R. A., Dunlosky, J., \& Kornell, N. (2013). Self-regulated learning: Beliefs, techniques, and illusions. Annual Review of Psychology, 64, 417-444. https://doi.org/10.1037/e676252012-083

Brookfield, S. D. (2015). The skillful teacher: On technique, trust, and responsiveness in the classroom (3rd ed.). Jossey-Bass Higher and Adult Education.

Cowling, M., \& Birt, J. (2018), "Pedagogy before technology: A design-based research approach to enhancing skills development in paramedic science using mixed reality". Information, 9(2), 29. https://doi.org/10.3390/info9020029

Cox, D., \& Prestridge, S. (2020). Understanding fully online teaching in vocational education. Research and Practice in Technology Enhanced Learning, 15(16). https://doi.org/10.1186/s41039-020-00138-4

Cox, D., \& Prestridge, S. (2019) In Shih, J. L. et al. (Eds.) (2019). Proceedings of the 27 the international conference on computers in education. Asia-Pacific Society for Computers in Education

Credé, M., \& Phillips, L. A. (2011). A meta-analytic review of the motivated strategies for learning questionnaire. Learning and Individual Differences, 21(4), 337-346. https://doi.org/10.1016/j.lindif.2011.03.002

Dalgarno, B., Hedberg, J., Harper, B., Williamson, A., Gunn, C., Young, A., \& Clear, T. (2002). The contribution of 3D environments to conceptual understanding. 149-158. https://www.ascilite.org/conferences/auckland02/proceedings/papers/051.pdf

Herrington, J. (2006). Authentic e-learning in higher education: Design principles for authentic learning environments and tasks. In T. Reeves \& S. Yamashita (Eds.), Proceedings of world conference on E-Learning in corporate, government, healthcare, and higher education 2006 (pp. 3164-3173). https://doi.org/10.4018/978$1-59140-594-8 . \operatorname{ch} 001$

International Labour Organization. (2021). Skills development in the time of COVID-19: Taking stock of the initial responses in technical and vocational education and training. https:/www.ilo.org/skills/areas/skills-training-forpoverty-reduction/WCMS 766557/lang--en/index.htm

Kearsley, G., \& Shneiderman, B. (1998). Engagement theory: A framework for technology-based teaching and learning. Educational Technology, 38(5), 20-23.https://doi.org/10.1007/BF02299671

Kohnke, L., \& Moorhouse, B. L. (2021). Adopting HyFlex in higher education in response to COVID-19: students' perspectives. Open Learning: The Journal of Open, Distance and e-Learning, 1-14. https://doi.org/10.1080/02680513.2021.1906641

Latchem, C. (2017). Using ICTs and blended learning in transforming TVET. UNESCO and Commonwealth of Learning.

Likert, R. (1932). A technique for the measurement of attitudes. Archives of Psychology, 22(140), 1-55.

Maclean, R. and Lai, A. (2011) Editorial. International Journal of Training Research, 9(1-2), 2-15. https://doi.org/10.5172/ijtr.9.1-2.2

Mason, J., \& Carr, D. (2020). Boosting lifelong learning through digital online education: Australian perspectives and practices. Advanced in Social Science, Education and Humanities Research, 548, 129-136. Proceedings of the first transnational webinar on adult and continuing education (TRACED 2020). https://doi.org/10.2991/assehr.k.210508.024

Moffett, J. (2014). Twelve tips for flipping the classroom. Medical Teacher, 37(4). https://doi.org/10.3109/0142159X.2014.943710

Norton, L. (2018). Action research in teaching and learning: A practical guide to conducting pedagogical research in universities (2nd ed.). Routledge. https://doi.org/10.4324/9781315147581

Pintrich, P. (2004). A conceptual framework for assessing motivation and self-regulated learning in college students. Educational Psychology Review, 16(4), 385-407. https://doi.org/10.1007/s10648-004-0006-x

Pintrich, P R, Smith, D A, Garcia, T \& McKeachie W J (1991). A manual for the use of the motivated strategies for learning questionnaire. National Center for Research to Improve Postsecondary Teaching and Learning, University of Michigan, Ann Arbor, MI. 
Salmon, G. (2000). E-Moderating: The Key to Teaching and Learning Online. Kogan Page.

Schmidt, S. (2017). Context and capabilities: tensions between managers' and teachers' views of advanced skills in VET. International Journal of Training Research, 15(1), 41-54.

https://doi.org/10.1080/14480220.2017.1331862

Simon, L., \& Beddie, F. (2017). Explaining the VET Applied Research Development Framework. NCVER.

Venkatesh, V.; Morris, M. G.; Davis, G. B.; Davis, F. D. (2003), "User acceptance of information technology:

Toward a unified view", MIS Quarterly, 27(3), 425-478. https://doi.org/10.2307/30036540

Vanderburg, R., Cowling, M., \& Dargusch, J. (2021). pedagogy before technology: Understanding the confidence of vocational educators for integrating technology enhanced learning. In Gregory, S., Warburton, S., \& Schier, M.

(Eds.), Back to the Future - ASCILITE '21. Proceedings ASCILITE 2021 in Armidale (pp. 111-120).

https://doi.org/10.14742/ascilite2021.0115

Note: All published papers are refereed, having undergone a double-blind peer-review process.

The author(s) assign a Creative Commons by attribution licence enabling others to distribute, remix, tweak, and build upon their work, even commercially, as long as credit is given to the author(s) for the original creation.

(c) Vanderburg, R., Cowling, M., \& Dargusch, J. 2021 